Institute of $\mathbf{F}_{\text {ood and }} \mathbf{A}$ gricultural $\mathbf{S}_{\text {ciences }}$

\title{
Macronutrient Deficiencies in Citrus: Nitrogen, Phosphorus, and Potassium ${ }^{1}$
}

Mongi Zekri and Thomas A. Obreza ${ }^{2}$

Perhaps the most distinctive observation about citrus nutrition is the variety of nutrient deficiencies that can appear under intensive cultivation. Visual deficiency symptoms of N, P, K, Ca, Mg, Fe, Zn, Mn, $\mathrm{B}, \mathrm{Cu}$, and Mo have been recognized both in the field and in artificial growing media. Nutrient deficiencies can usually be recognized by distinctive symptoms that most often occur in the leaves, but can sometimes be seen in the fruit, branches, or general growth of the tree. In some cases, a combination of deficiencies, excesses, or both may mask typical symptoms of a single element and make positive visual identification more difficult. In such cases, leaf analysis can provide a more accurate identification. The degree of deficiency may be measured by the severity of the symptoms and the number of growth terminals affected. Citrus growers should be able to recognize deficiency symptoms, know the treatment necessary to correct them, and be cautious about confusing deficiency symptoms with conditions resulting from diseases, insects, nematodes, flooding, or other causes.

The use of specific symptoms as guides to the nutritional needs of citrus trees has been common for many years. The symptoms of $\mathrm{N}, \mathrm{Mg}, \mathrm{Fe}, \mathrm{Zn}, \mathrm{Mn}$, and $\mathrm{Cu}$ deficiency are quite definite and easily recognizable. This information has been of great value as a guide to the nutritional needs of the tree. Mineral deficiency has been much more widely observed in Florida than other citrus-growing areas because of the sandy, low organic matter soils, heavy leaching rains, and large crops that remove substantial amounts of nutrients.

\section{Nitrogen (N)}

Trees grown where plant-available $\mathrm{N}$ is limited may appear nearly normal but are undersized. Such trees carry little or no fruit load, and can be highly erratic in bearing habit. They bloom sparsely, flush irregularly, and produce limited twig and leaf growth. Severe N starvation causes a general yellowing of the foliage. This symptom can be particularly noted on well-nourished trees that have subsequently had their $\mathrm{N}$ supply reduced sharply.

Nitrogen deficiency first appears on older leaves and proceeds toward the younger leaves. Deficiency symptoms are characterized by light yellowish-green leaves. The veins are only slightly lighter in color than the tissue in between. New leaves are small, thin, fragile, and light green in color. Leaves on new flushes are greener than leaves on the old flushes.

1. This document is SL 201, a fact sheet of the Soil and Water Science Department, Florida Cooperative Extension Service, Institute of Food and Agricultural Sciences, University of Florida. First printed: January 2003. Please visit the EDIS Web site at http://edis.ifas.ufl.edu.

2. Mongi Zekri, Multi-County Citrus Agent, Hendry County Extension Office and Thomas A. Obreza, Professor, Soil and Water Science Department, Florida Cooperative Extension Service, Institute of Food and Agricultural Sciences, University of Florida, Gainesville, 32611-0290. 
Mature green leaves slowly bleach to a mottled irregular green and yellow pattern, become entirely yellow, and then are shed. Trees are stunted with a thin canopy, and the crop is reduced. The color of the fruit peel tends to be pale and smooth, and the juice has lower soluble solids and acid concentrations. If $\mathrm{N}$ is deficient during the summer and fall when the fruit is expanding and maturing, some of the green leaves will turn yellow and may shed. A pattern resembling $\mathrm{Mg}$ deficiency symptom can occur under such conditions. Trees that are constantly short of $\mathrm{N}$ are stunted with irregular and very short twig growth. Twig dieback can occur and crop production is greatly reduced.

The ability to distinguish between $\mathrm{N}$ deficiency and the deficiency of other elements is very important. Symptoms of Mg deficiency at later stages can be confused with $\mathrm{N}$ deficiency. It must always be remembered that yellow leaves are not necessarily an indication of $\mathrm{N}$ deficiency. Nitrogen deficiency can be distinguished by the general nature of the yellowing of the foliage over the entire tree with the absence of any distinctive leaf pattern. Nitrogen deficiency in Florida is most likely to be observed after flowering but before the summer rainy season begins. In many cases, the foliage of such trees will become greener during the summer rainy season, particularly if a small crop has set. Magnesium deficiency develops in the summer and may cause a complete yellowing of the leaves in the fall or early winter with no possible regreening unless $\mathrm{Mg}$ fertilizer is applied.

The main cause of $\mathrm{N}$ deficiency is a lack of available $\mathrm{N}$ in the soil, which can be due to a number of factors. Nitrogen leaching is caused by the combination of heavy summer rainfall or over-irrigation with highly-porous soil. Water-logging of the soil can cause $\mathrm{N}$ loss through denitrification that may lead to a temporary $\mathrm{N}$ deficiency that is relieved by dry weather. Weak or old trees deficient in $\mathrm{N}$ can be improved by applying supplementary $\mathrm{N}$ fertilizer in frequent applications. The use of low-biuret urea as a foliar spray is a very efficient and rapid way to correct $\mathrm{N}$ deficiency.

\section{Phosphorus (P)}

Growth is reduced when the supply of $\mathrm{P}$ is too low. Phosphorus moves from older to younger tissues. Therefore, deficiency symptoms appear first on older leaves, which lose their deep green color. Leaves are small and narrow with purplish or bronze, lusterless discoloration. Some leaves may later develop necrotic areas and young leaves will show reduced growth rate. Leaves shed prematurely and fruit can drop before normal harvesting time. Trees will exhibit limited flower development with reduced fruit set and fruit yield. The fruit will be coarse and rough in texture with a coarse, thick rind and a hollow core. The fruit will also have a high acidity in proportion to total soluble solids. Thus, fruit maturity will be delayed. Usually, the roots are stunted and poorly branched.

The cause of $\mathrm{P}$ deficiency is a lack of available $\mathrm{P}$ in the soil. Phosphorus deficiency may occur in areas of high rainfall due to leaching and erosion. In strongly acidic soils, $\mathrm{P}$ can become quickly unavailable. Phosphorus availability is also reduced in calcareous soils. Phosphorus deficiency can be corrected by applying water-soluble $\mathrm{P}$ fertilizer to the soil after confirmation of $\mathrm{P}$ deficiency by leaf and soil analysis.

\section{Potassium (K)}

The rate of photosynthesis drops sharply when plants are $\mathrm{K}$ deficient. Too much $\mathrm{N}$ with too little $\mathrm{K}$ can result in a back-up of the protein building blocks, set the stage for disease problems, reduce production of carbohydrates, reduce fruiting, and increase fruit creasing, plugging and drop. A shortage of K can result in decreased yield and low fruit quality. Moderately low concentrations of $\mathrm{K}$ in the tree will cause a general reduction in growth without visual deficiency symptoms. The onset of visual deficiency symptoms means that production has already been seriously impaired.

In Florida, low K fertilization can lead to deficiency symptoms that develop in late summer and fall on the recently matured spring flush leaves. When $\mathrm{K}$ is low, the general leaf pattern begins as a yellowing of the tips and margins, which then gets broader. Necrotic areas and spotting can develop on 
the leaves. Symptoms appear first on older leaves

because $\mathrm{K}$ tends to concentrate in the rapidly growing tissues. Potassium deficiency will cause slow growth, small leaves, fine branches, compact tree appearance, an increase in susceptibility to drought and cold, reduction in fruit size, very thin peel of smooth texture, premature shedding of fruit, and lower acid concentration in the fruit.

Potassium deficiency symptoms usually result from an insufficient $\mathrm{K}$ supply in the soil. Potassium deficiency may occur on acid sandy soils where leaching may be considerable. The supply of $\mathrm{K}$ to plants may be decreased by soils that have very high concentrations of $\mathrm{Ca}$ and $\mathrm{Mg}$ or by heavy application of N. Decreased K uptake is typical on some calcareous soils. Lack of soil moisture also reduces $\mathrm{K}$ uptake and may lead to $\mathrm{K}$ deficiency. If the supply of $\mathrm{N}$ and $\mathrm{P}$ is high relative to that of $\mathrm{K}$, growth may be rapid at first, but the $\mathrm{K}$ concentration in the plant may ultimately decrease to deficiency. Addition of $\mathrm{K}$ would be necessary to maintain the nutrient balance required for uniform and continued growth. In situations where available $\mathrm{K}$ is high compared with the $\mathrm{N}$ or $\mathrm{P}$ supply, luxury consumption of $\mathrm{K}$ can occur.

Under most soil conditions, $\mathrm{K}$ deficiency can be corrected by applying potassium chloride (muriate of potash) or potassium sulfate to the soil. However, in fine textured, saline, or calcareous soils, $\mathrm{K}$ applications to the soil are sometimes ineffective or slow to correct K deficiency. Foliar application of potassium nitrate or mono-potassium phosphate can be very effective and rapid to correct $\mathrm{K}$ deficiency. 